\title{
The Cinema of Katinka Heyns
}

\author{
By Martin P. Botha \\ Spring 2015 Issue of KINEMA \\ THE CINEMA OF KATINKA HEYNS
}

In the 119-year history of South African cinema only two books have been devoted to South African film directors: Martin Botha and Hubert Dethier's Kronieken van Zuid-Afrika: de films van Manie van Rensburg (1997) and Martin Botha's Jans Rautenbach: Dromer, Baanbreker en Auteur (2006). ${ }^{(1)}$

In general the artistic achievements of film directors received little scholarly attention. Attempts to rework the history of South African cinema such as Isabel Balseiro and Ntongela Masilela's edited volume, To Change Reels: Film and Film Culture in South Africa (2003) as well as Jacqueline Maingard's South African National Cinema (2007), devoted entire chapters to the ideological analysis of films such as De Voortrekkers (1916), Cry, the Beloved Country (1951) and Come Back, Africa (1959), but in the process they ignored the significant oeuvres of directors such as Ross Devenish, Manie van Rensburg, Jans Rautenbach, Katinka Heyns, Darrell Roodt as well as many of the directors of the 1980s.

Surprisingly, Heyns and Roodt, and other significant (and internationally acclaimed) post-apartheid directors such as Gavin Hood, Mark Dornford-May, Rehad Desai, Francois Verster, Ramadan Suleman, Madoda Ncayiyana, Craig Matthew, Craig and Damon Foster, Jack Lewis, Liz Fish and Ntshaveni Wa Luruli, are absent from the list of 25 film-makers and cultural leaders whom the American scholar Audrey Thomas McCluskey interviewed for her publication on post-apartheid cinema titled The Devil You Dance With: Film Culture in the New South Africa (2009).

South African film production was dominated by male directors until 1962. A breakthrough came in 1962 with the neo-noir thriller Man in die Donker by director Truida Pohl. Throughout the history of South African cinema only a few female directors managed to make features (Diana Ginsberg, Anna NeethlingPohl, Marie du Toit, Louise Smit, Katinka Heyns, Elaine Proctor, Helena Noguiera, Jean Stewart, Stefanie Sycholt, Amanda Lane, Meg Rickards, Claire Angelique, Minky Schlesinger, Jann Turner, Sara Blecher and a few others), and only since the mid-1990s have black female directors been able to break into the feature and short film industry (for example Palesa Nkosi, Xoliswa Sithole, Meganthrie Pillay, Zulfah Otto-Sallies, Shamim Sharif, Rayda Jacobs, Joyti Mistry and Jayan Moodley).

Katinka Heyns has emerged as one of the outstanding multi-award winning film actresses and directors in South African cinema (Botha 2012). She was born in 1947. Heyns graduated at the University of Pretoria with a BA degree in Drama (cum laude). Her involvement in the film industry started in 1969 in Jans Rautenbach's Katrina, in which she played a white girl who unknowingly falls in love with a 'coloured'(2) boy. She then played demanding character roles in other Rautenbach features like Janie Tocsins (1970), Pappa Lap (1971) and Eendag op 'n Reëndag (1975), for which she won a Rapport Oscar for Best Actress. She became a well-known television actress in the comedy series Willem by director Manie van Rensburg. She also appeared in many theatrical productions staged by the former Performing Arts Councils in the Transvaal and Cape provinces.

In 1974 Heyns founded her own production company, Sonneblom Films. After the introduction of television in South Africa Heyns also directed quality documentary programmes about famous literary figures such as N. P. Van Wyk Louw, for which she won an award by the Suid-Afrikaanse Akademie vir Wetenskap en Kuns (South African Academy of Arts and Science). Since the 1980s television dramas and series followed: Piet-My-Vrou (1981), Tekwan (1985), Die Avonture van Joachim Verwey (1980), Die Dood van Elmien Adler (1983, as producer), Simon en Sandra (1989) and for the pay channel M-Net, Amalia (2005). Numerous educational and children television programmes were also made.

She has twice been the recipient of the prestigious Medal of Honour from the South African Academy of Arts and Science, and has also received the Legendary Award for Woman in Film and Television International Crystal Awards (Botha 2012). On 14 April 2011 Heyns received an honorary doctorate from the Drama Department of the University of Pretoria. 
Heyns has been acclaimed in South Africa and abroad for four outstanding award winning features that deal with the female psyche in a very sensitive way: Fiela se Kind (Fiela's Child, 1987), Die Storie van Klara Viljee (1991), Paljas (1997) and Die Wonderwerker (2012).

Collaborative authorship in the cinema of Katinka Heyns

This article forms part of an ongoing investigation into the cinema of Katinka Heyns, in particular her role as director. Her collaboration with key figures in her career such as screenwriter Chris Barnard and director/cinematographer Koos Roets has been examined. The study is a combination of historical research, interviews with Heyns, as well as textual analysis. It follows the same methodology as in the case of previous auteur studies on South African film directors namely Manie van Rensburg (Botha \& Dethier 1997) and Jans Rautenbach (Botha 2006).

Debates about auteurism in the cinema occupied a privileged position in film studies from the 1950s until the early 1980s (Caughie 1981; Cook 2007; Maule 2008; Sellors 2010). Pam Cook's overview in The Cinema Book (2007) of the developments in auteurism from the 1950s till the $21^{\text {st }}$ century is very useful. During the 1950s and 1960s the term auteurism presupposes a dominant creative force, the auteur, which controls and choreographs the multiple voices at work in a film. Auteur analysis usually involved an examination of a recurring set of themes in the oeuvre of a film director, as well as a singular vision, indeed a distinctive world view. Analysts focused on a specific director's singular manner of putting objects and people into motion, what French auteurists referred to as mise-en-scene.

In theoretical debates of the last decades, as film scholars we find decided shifts from the emphasis on the director as the author to the significance of the spectator, and eventually a return to a reborn author (both commercially conditioned and theoretically refurbished) as cinema's privileged source of meaning (Cook 2007). These different concepts of authorship likewise entail different notions of spectatorship.

In his work, C. Paul Sellors (for example Sellors 2007; 2010) argued that authorship is a problem in film studies that simply will not go away. Despite all sorts of arguments in the past that reduced film authors to abstract entities such as author-functions, fictional surrogates, and implied authors, and eventually even abandoning them under the mantra of "the death of the author," film scholars have not been able in their critical and historical discourses to shrug off talking about films as if they are the products of real individuals. Sellors claims that only by first understanding what authorship is, can film scholars proceed to investigate issues such as artistic authorship or the way that authorship fits within a wider socio-cultural framework.

According to Sellors, authorship is not a concept to be derived from a text but an intentional action of an intending agent that causes a text. He argues the causal party behind the communication of the media in question is the author. This concept is not exclusive to a single person, but rather, it can be applied broadly to the director and the writer if they all play a part in producing the film. The contributions of the cinematographer and the editor also cannot be ignored in bringing the moving image to the screen. Films are not created by a single consciousness. They come together as part of the collective effort by artists and technicians. Collaborative authorship comes from a group intentionality moving towards a common goal. Unfortunately many auteurists have tried to explain a film's coherency by overvaluing the authorial control and artistic aptitude of an individual. In many cases films have been shaped by joint authorship, for example, the significant contributions by screenwriters and/or cinematographers.

Katinka Heyns' oeuvre (television and cinema) is a complex case for auteur study. Heyns' work has been applauded for the way in which her films both celebrate and interrogate Afrikaans culture and female identity. On the whole, her films are attempts at cultural decolonisation and re-imagination that repositions Afrikaans film in the greater cinematic and scholarly landscapes. Her television work demonstrates a commitment to resurfacing and reframing historical figures and repositioning their work in the current South African milieu. Her current work on mental illnesses with her son Simon Barnard, her creative signature with its emphasis on female voices and her interrogation of the challenges of living in a changing South African society demonstrates a dedication to projecting local concerns into a global arena. The significant contribution of screenwriter Chris Barnard however, can't be ignored in any auteur study of her work. Barnard wrote the screenplays of all her features Fiela se Kind (1987), Die Storie van Klara Viljee (1991), Paljas (1997) and Die Wonderwerker (2012), as well as television series and dramas such as Die Avonture van Joachim Verwey (1980), Piet-My-Vrou (1981), Tekwan (1985) and Waar die liefde lê (1983) - (see for example Barnard 1998). 
Christiaan Johan Barnard (aka Chris Barnard) is a leading South African author born 15 July 1939. He is well known for various Afrikaans novels (for example, Mahala 1971 and Moerland 1982), short stories, plays, film scripts and television dramas. During the 1960s, he and several other authors were ground-breaking figures in the Afrikaans literary movement known as Die Sestigers ("The Sixtyers") - (see Kannemeyer 1988). These writers sought to use Afrikaans as a language to speak against the apartheid government, and also to bring into Afrikaans literature the influence of contemporary English and French trends. He won more than 20 awards for his literary work and screenplays. He married Heyns in 1978. I will highlight his seminal contribution to Heyns' features in the next part of this article.

Another important creative force in Heyns' oeuvre is Koos Roets, one of the leading cinematographers in South Africa. Heyns acted in some of his earlier films, such as Die Sersant en die Tigermoth (1973) and Babbelkous en Bruidegom (1974). When she moved on to directing Roets became the cinematographer of a substantial part of her television work (for example, Die Avonture van Joachim Verwey, Tekwan, The Feast of the Uninvited), as well as all her features since Die Storie van Klara Viljee.

Contextualisation

Publications by Gutsche (1972), Le Roux and Fourie (1992), Maingard (2007), Balseiro and Masilela (2003), Botha and Van Aswegen (1992), Blignaut and Botha (1992), Botha and Dethier (1997), Davis (1996), Louw and Botha (1993) and Tomaselli (1989) documented developments in South African cinema. A critical overview of the fragmentation of the South African film industry during apartheid is presented by Botha (2012). The history of South African cinema is also chronicled in full-length documentaries and television series: Wayne Lines's The Saga of the Silver Screen (1987), Peter Davis's In Darkest Hollywood: Cinema and Apartheid (1993), Katinka Heyns's Silwerdoekstories (1994), Taryn da Canha's Redefining the Griot: A history of South African documentary film (2003), Neil Sandilands's Impresario (2010) and the television series Daar doer in die fliek (2011).

A discussion of Heyns' oeuvre needs to take the history of South African cinema, as well as the country's history into account. Her work simply can't be separated from the developments in South African cinema and television during the past 40 years. Her career as film actress started in the ground-breaking films by Jans Rautenbach, during a time when South African cinema hardly reflected the socio-political realities of the country (Botha 2012). These films were made during the time of very strict moral and political censorship in South Africa (Burns 1990; Ozynski 1989; Tomaselli 1989).

In 1969 Rautenbach directed Katrina, one of the most innovative films to come out of the apartheid years of the sixties. Based on a powerful play by D. Warner, Try for White, is, for its time, a shocking exposé of the horrors of apartheid and the racial classification system. The film focuses on a 'coloured' woman, Katrina, who 'tries for white'. She renounces her mother and father to make a better life possible for herself and her son in apartheid South Africa. Her son is unaware of his roots and is dating a white girl (played by Heyns). A white Anglican priest, Alex Trewellyn, falls in love with Katrina, and their lives are shattered when the secrets are revealed (Botha 2006; 2012). Rautenbach received death threats from the far right wing in South Africa and had to battle the censors in South Africa to make this film. Chief censor Janie Kruger wanted to cut several scenes (Botha 2006). Katrina continues Rautenbach's theme of cultural identity. In this case, the impact of the apartheid state on the identities of South Africans has been examined, together with white racism and the biases of the white Afrikaner nation.

In Janie Tocsins (1970), his next feature, Rautenbach uses a mental institution as an allegory of South African society under apartheid. The situation in the film represents a microcosm of South Africa in 1970. The apartheid state has been represented as an asylum. The inmates are Afrikaner types such as a political right-winger (Don Leonard), a judge (Jacques Loots), a painter without arms, a girl with the mind of a child (Heyns) as well as an alienated English woman and one black person.

The film was unrivalled in contemporary South African cinema, but was an isolated case during the 1970s. Escapism dominated the output of the film industry. The images of Afrikanerdom by Rautenbach in Janie Tocsins certainly did not meet the expectations of audiences. They rejected these films and rather flocked to those who portrayed them as chatty, heart-warming and lovable. Their conception of socio-political reality was confined to the conventions of Afrikaans melodramas about mismatched couples who had to overcome obstacles on the path to true love (Botha 2006; 2012). Several outstanding South African film professionals 
such as Katinka Heyns owe their developed careers to their work in Rautenbach films.

Heyns produced and directed drama series for the South African Broadcasting Corporation (SABC) from the late 1970s until the end of the 1980s. The advent of television in South Africa during 1976 gave many local filmmakers artistic opportunities that had not been available due to the ineffective subsidy scheme (see Botha 2012). Although censorship regarding political material was very tight at the SABC directors such as Heyns had an opportunity to do a variety of television dramas and series, as well as documentaries.

Film production, however, boomed during the mid-1980s owing to an additional funding system whereby films were tax deductible (Botha \& Van Aswegen 1992; Botha 2012). During the period 1984-86, film producers could rely on tax benefits to cover production costs and show a profit. Sadly, the system led to dozens of imitations of American genre films, which were chiefly released on video abroad. Several of these genre films merely used South African landscapes to depict another country or region, for example, Vietnam, South America, east or central Africa or an island in a vast ocean (Botha \& Van Aswegen 1992). But the boom also led to important developments, of which Heyns was a major player. She focused on South African stories with recognisable South African landscapes.

According to film historians, 1986/87 can be regarded as the turning point in the South African film industry (Tomaselli 1989; Botha 2012). Only then did several feature films begin to critically examine the South African milieu as well as apartheid and colonial history. One of the films was Fiela se Kind (1987). Fiela se kind was co-produced by Heyns and Edgar Bold, and is based on a popular novel by Dalene Matthee, about the fortunes of Benjamin, a white boy brought up by Fiela Komoetie, a 'coloured' woman of Wolwekraal in the Lange Kloof in the Cape during 1874. The boy, spotted by a census official, is brought before a magistrate's court and claimed by a white woman as the child she had lost some nine years earlier. The heartbroken Fiela tries to retrieve the boy now named Lukas but is blocked by an implacable colonial legal system with strong racist overtones. Lukas is also ill-treated by his new father.

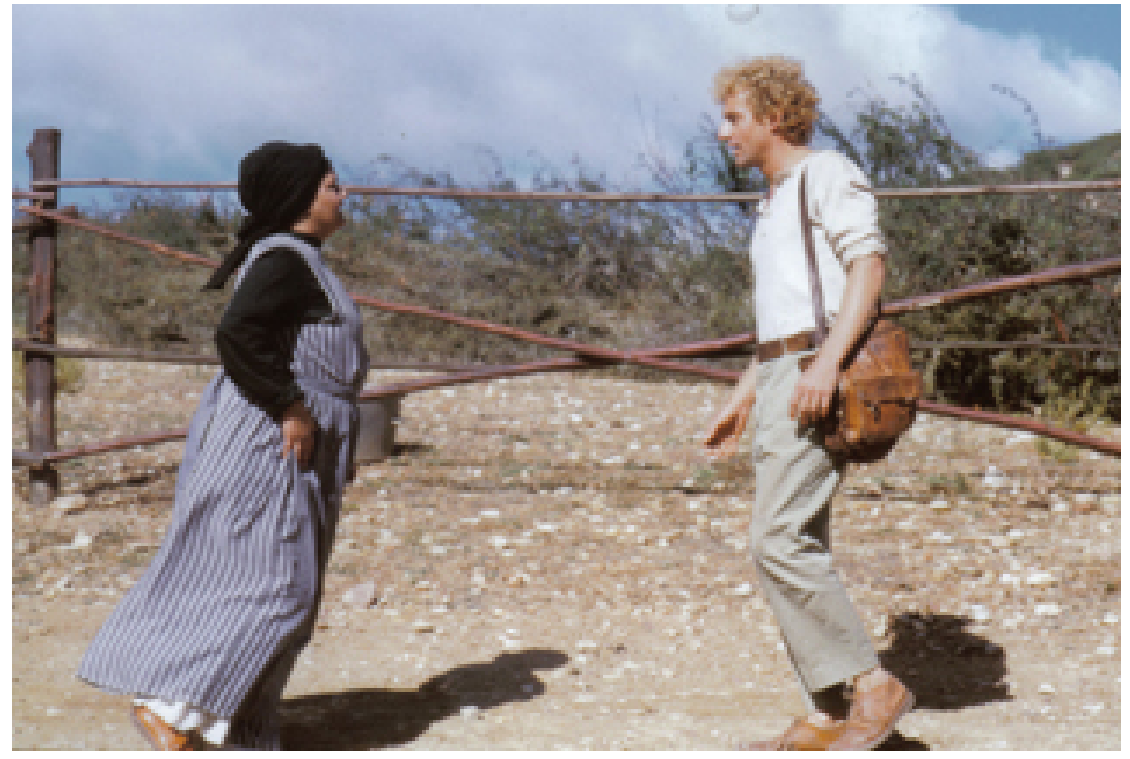

Figure 1: Fiela's Child

Bischoff (2009) notes that the two families are harshly contrasted in the novel and the film, offering a penetrating take on racial issues in South Africa at the time: Fiela's family is deeply religious, has dignity and integrity, and makes a living from hard, honest work, while the white "bos" (bush) family has an educated, abusive and racist father, lives in abject poverty and does not respect the forest environment. Benjamin is finally re-united with Fiela as an adult and she offers him his rightful inheritance and ownership of the farm on which the family lives. Although the character of Fiela offers a challenging example of a strong woman prepared to take on the colonial authorities for what she believes is just - made even more piercing because she is coloured - the ending of the film is problematic and indicative of an apartheid world-view still 
in place during the 1980s. By reinstating Benjamin, the white male, as the rightful owner of Fiela's farm, the film is reinforcing the social and economic hierarchies of apartheid ideologies. But the film remains a powerful portrayal of social injustice in colonial South Africa and although set between 1874 and 1886 the film exposes the roots of apartheid. In it, the colonial rulers claim the right to make life-splintering decisions purely on the basis of race (Botha 2012).

Ironically, Heyns did not consider the story in terms of colour. She stated that it is not a story about a coloured woman raising a white child but the story of a mother and a child, and the child being taken away from her. She described the story as a fairy tale, as the severe struggle of the hero against all odds. Chris Barnard wrote the screenplay over a period of six months. Matthee gave them free reign. The screenplay follows the novel closely, both in terms of the development of the action and the dialogue (Botha 2012).

South African critics praised the film in terms of its exposé of crucial socio-political issues in a sophisticated yet in a warmly human, non-melodramatic way. In the principal part of Fiela actress Shaleen Surtie-Richards gave a riveting marrow-and-bone portrayal. It won her an AA Life/M-Net Vita Film Award as Best Actress in 1988. The film was also applauded for the visual evocation of novelist Matthee's three symbolic landscapes - the plains of the Lange Kloof, the forest of Kom-se-Bos and the sea around the Knysna Heads. Further praise came from critics with regard to the excellent use of music, including haunting pan pipes.

The images of womanhood are also deeply moving, and issues around the oppression of women are subtly raised. The film won numerous AA Life/M-Net Vita Awards in 1988, including Best South African Film and Best Director (Katinka Heyns). The contribution by James Robb (cinematographer) and Avril Beukes (editing) was also applauded. The film, which was released abroad, was also a huge success at the South African box office.

During the 1990s, Afrikaans cinema almost disappeared (Botha 2012). A few films made an impact. The story of Heyns's second feature Die Storie van Klara Viljee (1991) takes place in a small coastal town in the 1950s and deals with the self-imposed exile of a woman due to mysterious events. Like in Fiela se Kind, the film is a sensitive and moving portrayal of women. It was considered by many critics to be a profound feminist statement (Botha 2012). The principal character, Klara, sets in motion a process of almost magical transformation of patriarchy-shattering proportion in a small southern Cape village. Robbed by the ocean of her dad, as well as her boyfriend, she decides to deny the sea's presence by building her house on the landward side of a dune. When she learns that her boyfriend has actually never died and has in fact betrayed her, she begins to move the dune, using only a donkey and a plough. It seems to be an impossible task, but it is a strong metaphor for Klara's embracing of life after her denial of reality. The notion that men are in control of white Afrikaner society is subverted with subtlety. In the process of taking control of her life, Klara also influenced the lives of other women in the village and in some ways acts as the catalyst for their own emancipation from patriarchy (Bischoff 2009; Marx 2003).

The film became a highly acclaimed, box-office success during the early 1990s in South Africa and a showpiece for the talents of a formidable team of actors and crew members: Anna-Mart Van der Merwe, Trix Pienaar, Lida Botha, Wilma Stockenström, Sandra Kotze and Regardt Van den Bergh as actors, Ronelle Loots as editor and Heyns as director and co-producer. Cinematographer Koos Roets does wonders with the South African light in his hauntingly beautiful pastoral images of the coastal milieu (Botha 2012).

One of the greatest features to emerge out of South Africa since 1994 is Heyns' Paljas 1997). The narrative occurs in the 1960s, when poverty amongst Afrikaners was a reality and the South African Railways a key mechanism in Afrikaner affirmative action (Shepperson \& Tomaselli 2000). Heyns' third feature deals with the deterioration of an Afrikaner family isolated and shunned in the small community of Toorwater. Nothing seems to happen. Then a circus train loses its way and comes to rest in Toorwater, and a mysterious clown brings fresh magic to the stagnating family, but to the rest of the community, he poses a threat.

Screenwriter Barnard and Heyns brilliantly succeed in creating a metaphor for the Afrikaner family's turbulent emotional, cultural and ideological journey from the darkness of apartheid back to the light of postapartheid reconciliation - familial, cultural and political (a fine analysis of this film is provided by Marx, 2003). The word paljas means to use magic, and in the context of the film, it means to magically transform, to rid a community of its fears and uncertainties. Paljas won the Medal of Honour from the South African 


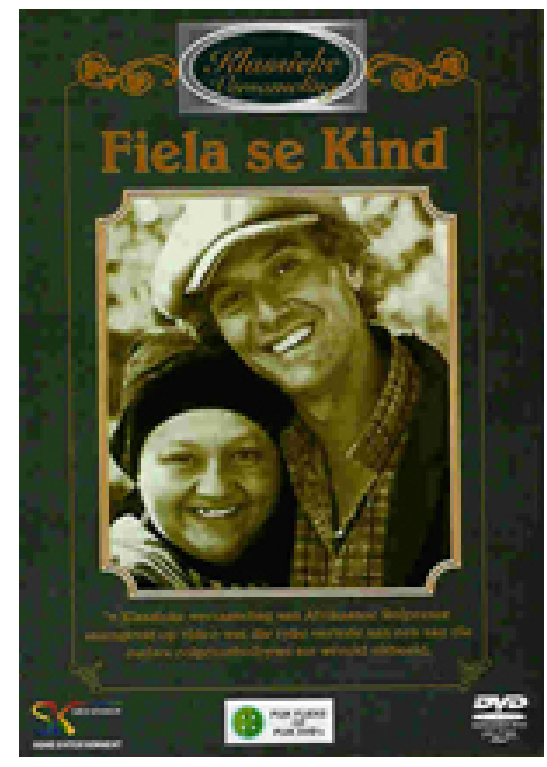

Figure 2: Fiela's Child (promotion poster)

Academy for Science and Arts, after being accepted as the first official entry from South Africa for the Oscar in the category of Best Foreign Language Film. An important professional relationship in Heyns' success remains with her husband, Chris Barnard, who wrote the screenplay. Paljas featured excellent ensemble acting by Marius Weyers, Aletta Bezuidenhout, Gerard Rudolf and Ian Roberts. The editing by one of South Africa's best editors, Ronelle Loots, also contributed to the quality of one of Heyns' best features to date.

Thematic concerns

In this auteur study it has been found that throughout her television and film dramas, director Heyns exhibits the same thematic pre-occupations, the same recurring motifs and incidents and basically the same visual style. Her work explores the psyche of South African females within a historical as well as a contemporary context (especially the period from 1874 to the 1960s). Her television series The Feast of the Uninvited (2008) is an important example.

At the end of the 1990s, South Africans participated in the centenary commemoration of the Anglo-Boer or South African War (1899-1902). The Anglo-Boer War broke out on 11 October 1899 between the two former republics (Free State and Transvaal) and Britain. As the war escalated Britain brought reinforcements from Australia, New Zealand and Canada as well as some volunteers from other British colonies. The war lasted three years with a very high casualty rate on both sides. Since the governments of the Free State and Transvaal were both elected by the white population, historians in the past generalised it by calling it a 'white man's war'. Apart from the fact that a war cannot be waged in a country without affecting all who live within its borders, recent archival research has proved that the black inhabitants of the two republics were affected more than was generally accepted (Le Roux 2009). Both sides used these people as scouts, labourers and even, at times, armed them, thus using them in a fighting capacity. The scope of the war was the biggest thus far on South African territory and one of the greatest thus far waged by Britain in southern Africa. The Boer forces had a potential of 54,000 men but never more than 40,000 were employed at once, whilst the British forces grew to 450,000 at the height of hostilities (see, for example, historical sources such as Cameron \& Spies 1986; Giliomee 2003; and Thompson 2001).

According to historians, 7,792 British soldiers were killed on the battlefields and 13,250 died from disease. On the Boer side, 6,000 died in military action and 26,370 women and children perished in the British concentration camps. The number of deaths of blacks in concentration camps has been estimated at 20,000 or more. Of special importance is the final phase of the war, after the capitals Bloemfontein and Pretoria were captured and the Boer forces resorted to guerrilla warfare. 
In an effort to contain the guerrillas, the British adopted a two pronged strategy: the so-called scorchedearth policy and the removal of the Boer women and children to concentration camps. It was during this phase of the war that the suffering of the black people intensified. Since about 30,000 farms were destroyed, livestock killed and crops burnt, the farm labourers and their families were taken to refugee camps. Because there was also fear amongst the British that those black farmers who farmed independently may supply the Boer commandos with victuals or that their livestock might be commandeered, these farmers were taken to concentration or labour camps. As the main reason for the war was the British desire to gain control of the gold mines in the Witwatersrand, there was a need to build a labour force with which to reopen the mines as soon as the state of hostilities allowed it. Forced labour camps were introduced and black labourers were concentrated therein.

The conditions in these camps were appalling. Epidemic diseases, malnutrition, insufficient medical care and dreadful sanitary arrangements resulted in the high death rate. In the white camps the death toll rose to 26,370 of the approximately 100,000 inmates. In the black camps the official British figure was just over 14,000 , but recent research proves that a figure in excess of 20,000 deaths among the 120,000 inmates of these camps is acceptable.

The traumatic memory of this war became an important theme in several post-apartheid productions such as Herman Binge's documentary Scorched Earth (2001), which examines the British concentration camp strategy during the war period as well as Heyns' The Feast of the Uninvited (2008).

In the first century of South African cinema, few filmmakers addressed the trauma of the concentration camps. The narrative of Die Bou van 'n Nasie (1938) includes a brief reference to the Anglo-Boer War, but nothing is mentioned about the concentration camps and the death of more than 26,000 Afrikaner women and their children. Afrikaans-language films in the 1960s such as Die Kavaliers (1966) and Krugermiljoene (1967) about the Anglo-Boer War were nostalgic and romantic period dramas, and in the case of the latter, even involved songs by South African artists Gé Korsten, Min Shaw and Brenda Bell. In Ross Devenish's masterful The Guest (1977), the traumatic memory of the war and the burnt farms is referred to in a conversation between Eugêne Marais and Tant Corrie.

Herman Binge's Scorched Earth draws on over 80 interviews conducted in both Britain and South Africa to examine the scorched-earth policy which led to the destruction of more than 30,000 farms and the subsequent relocation of Boer women and children as well as blacks to British concentration camps (Bickford \& Mendelsohn 2003). The documentary formed part of pay television M-Net's series on the devastation the war had on non-fighting civilians, especially women, children and the elderly (Le Roux 2009). Binge made extensive use of testimonies, photographs and conversations with several historians such as Fransjohan Pretorius and Albert Grundlingh to contextualise the historical events and narratives of trauma.

Heyns and writer P. G. du Plessis's The Feast of the Uninvited (2008) focuses on several families on both sides of the conflict who were traumatised by the war and the concentration camps. Starring an impressive ensemble of fine actors such as Jana Cilliers, Marius Weyers, Anna-Mart Van der Merwe, Cobus Rossouw, Rika Sennett, Louis Van Niekerk, Albert Maritz, Neil Sandilands, Marcel Van Heerden, Paul Luckhof, Hykie Berg and Stian Bam, the 350-minute production was commissioned by M-Net's Marida Swanepoel and produced by André Scholtz.

Cobus Rossouw serves as a narrator who fulfils various functions for the duration of the narrative. He reflects on the extent the stories in the mini-series are able to capture collective memory. He provides an important contextualisation of the historical events which frame the narrative. The narrator even engages the characters about their motives of joining the war as well as their post-war memories. It is a non-linear narrative structure which attempts to understand the sweep of history by focusing on the stories of ordinary people. At the beginning of the almost 7-hour epic the narrator invites the audience to a game of history.

The approach imagines ordinary people and their stories during and after the war experience. The characters are thus based on the imagined lives of various families, and the narrator admits that they could not be representative of the wider spectre of real-life participants in the war. The post-modern approach of screenwriter P.G. Du Plessis is ultimately highly successful and contributes to a very rich experience. The film examines in a very nuanced way a range of themes: the bitterness among Afrikaners after the war, 
ideological and class differences among Afrikaners as well as traumatic memories of war, especially by various female characters.

Ultimately the narrator argues it is almost impossible to tell the story of collective pain when it is on this scale. For example, 22,000 children died in the concentration camps in less than thre years. In the end we cannot really recall the pain of history. We can only put cold numbers to it, but statistics cannot move us. Numbers only astonish the brain, but the soul is left untouched.

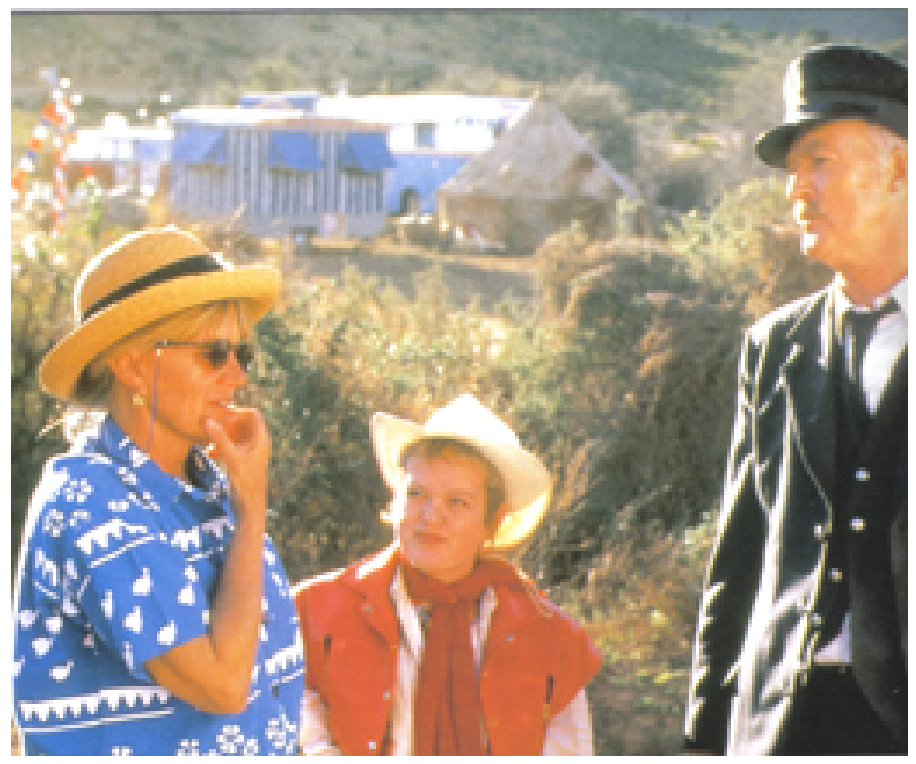

Figure 3: Katinka Heyns on the site of Paljas

Memories of this war and the imagined lives of historical figures such as Eugêne Marais form part of the narrative structure of Heyns' latest feature Die Wonderwerker (The Miracle Worker 2012). Heyns and Barnard brilliantly create a story of a Renaissance man (who also had a drug addiction which determined much of his life) who allowed his heart to wander. Marais was a great literary figure, but also an addict and a drifter. Heyns and Barnard circled a specific part of the poet/scientist's life to give an idea of who he was, instead of reaching much wider and losing the personality of the man. As in the case of Paljas he remains the outsider to a family, which he befriends. He becomes a catalyst in their domestic drama.

The story focuses on the few months he spends on the Van Rooyen's farm, where he falls in love with the 19-year-old Jane Brayshaw. She has been adopted. The farmer's wife, Maria (Cawood), falls in love with Marais but soon discovers his addiction to morphine. The family struggles financially. After the Anglo-Boer War nothing was left on the farm. It had a traumatic impact on Maria's husband, Gys van Rooyen (Marius Weyers). Their marriage seems to be strained and Marais' presence creates conflict between the members of the family. Barnard's screenplay never attempts to represent a complex portrait of Marais as a literary giant, scientist and healer. He functions more as a relational catalyst to his adopted family. Gys is a clenched, jealous and enraged husband.

In essence Die Wonderwerker is a family drama, not a historical representation of a well-known South African writer. The film is like Heyns' other features, a character-driven drama with Marais as the spanner in the works, playing off each of the characters. He's a mysterious stranger, one who seems to hold the answers to each of their problems but ironically, not his own. He functions as a catalyst to the dire situation they all find themselves in, developing their desires to a point of revelation, while trying to keep a lid on his own disappointments with drugs.

But ultimately, like in Paljas, Die Wonderwerker is predominantly about an Afrikaner family, isolated and dysfunctional in their interpersonal relationships, whose lives are irrevocably transformed when an outsider enters their lives. 
Koos Roets' cinematography once again adds to a celebration of South Africa's landscapes: the coastal milieu of Die Storie van Klara Viljee, Small Karoo setting of Paljas and beautiful mountain ranges and rocky landscapes of Die Wonderwerker are masterful tributes to Heyns' visualisation of Barnard's screenplays. Nature's beauty is juxtaposed with the alienating humanity as Marais speaks of termites functioning as one against the backdrop of a family doing the opposite and seemingly falling apart. Die Wonderwerker, in a way, celebrates the 36-year collaboration between Heyns and Chris Barnard. He is the creator of the text and characters. In all Heyns' features, her direction serves the characters. The intention was to create historical fiction and nothing more. The imagined lives in the story were based on oral accounts, bits and pieces in journals, as well as letters. Barnard developed his screenplay from popular memory.

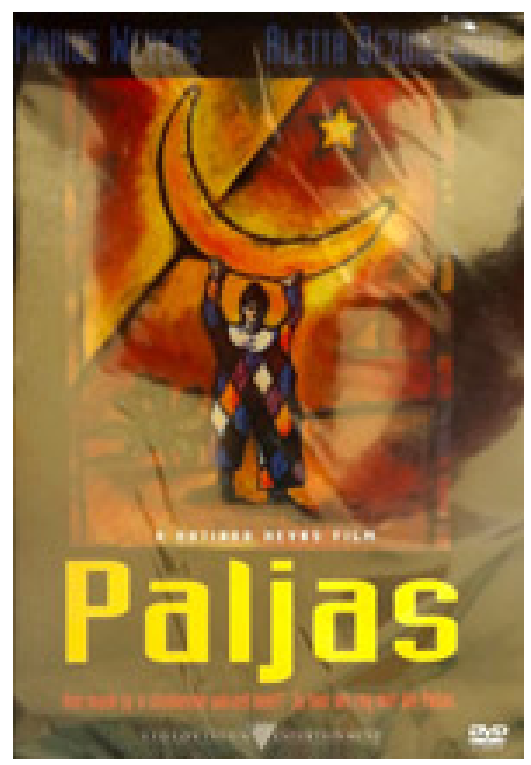

Figure 4: Paljas (publicity cover)

The finest directors in South African cinema, Manie van Rensburg and Jans Rautenbach, could be described as chroniclers of South African history. Van Rensburg explored the psyche of the Afrikaner within a historical as well as a contemporary context. He was preoccupied with communication problems between people, especially within love relationships. The outsider is a dominant figure in his universe. Themes that Van Rensburg tends to portray in his chronicles are the psyche of the Afrikaner in a contemporary or historic situation (especially the period from the 1920s to the 1940s); the way of life of, and motivation for, individuals living on the edge of society; loneliness; and the exploration of the communication potential of film and television to convey contextual and experiential information to the viewer (Botha 2012). Van Rensburg's unique style, his treatment of location, time and place, as well as his thematic concerns of the political realities of South Africa during the previous century, is almost unrivalled in our film history (Botha \& Dethier 1997).

The portrayal of communication problems between people and a unique historical documentation of Afrikaner culture make Jans Rautenbach also a chronicler of this part of South African society (Botha 2006). Heyns and Barnard should also be regarded as major chroniclers, especially with regard to the four features. Sociopolitical events form an important background to the family dramas. South African landscapes are equally important. An important addition to Heyns' chronicles is the strong emphasis on the female psyche: the women in all four films and especially white and black females in The Feast of the Uninvited.

Afrikaans language resistance and counterculture filmmaking is rarely recognised as a part of the African cinema canon, yet Heyns has had a long career in contributing to visions of Africa. In light of her role as a woman filmmaker in Africa, as an author who has consistently challenged repressive systems of representation, and who at the same time has succeeded in telling extraordinary stories, she should be the focus of further studies. 
From historical concerns to the now

Heyns' most notable presence in a film recently has been Living with Bipolar Disorder (2009). It is a documentary about a young film director, 27-year-old Simon Barnard, son of Heyns and Barnard, and his affliction with bipolar disorder. In the documentary there is a dramatisation of Simon's attempted suicide, a horrific scene and reconstruction of the event in which Heyns participated. He tried to hang himself and she found him at the spot. The sheer emotional impact of her interview, in which she shares her experience, is devastating. The private becomes public.

The mental state of a character in contemporary South Africa will be explored in Barnard's reworking of his 1971 play Die Rebellie van Lafras Verwey (The Rebellion of Lafras Verwey).

And last year Heyns directed some of the scenes of Jans Rautenbach's highly personal film Abraham, in which he portrays himself.

In retrospect one notes particular sentiments in Heyns' cinematic universe. Her documentary Prof Martin Versfeld (1989) provides the key. Versfeld was a well-known former Professor of Philosophy at the University of Cape Town. He was born in Cape Town in 1909. He wrote several books "that strayed far from academic concerns", including Klip en Klei (about the philosophy of houses), Die neukery met die Appelboom (The trouble with the apple tree), Pots and Poetry and Food for Thought: A Philosopher's Cookbook. He died in 1995.

He will be remembered for his earthy wisdom. As in the case of her features the approach to this documentary is lyrical and sensitive. Heyns emphasises the humanity of the philosopher. In one beautiful shot, Versfeld is playing a musical instrument surrounded by the pastoral beauty of the landscape. His earthiness, connection to the soil is highlighted. And that earthiness of ordinary and more exceptional characters such as Marais in Die Wonderwerker seems to intrigue Heyns throughout her body of work. Her work is noted for the humane treatment of the characters, including outcasts, without moral judgment. It is a lyrical cinema with a deep-felt humanism, a significant result of collaborative authorship.

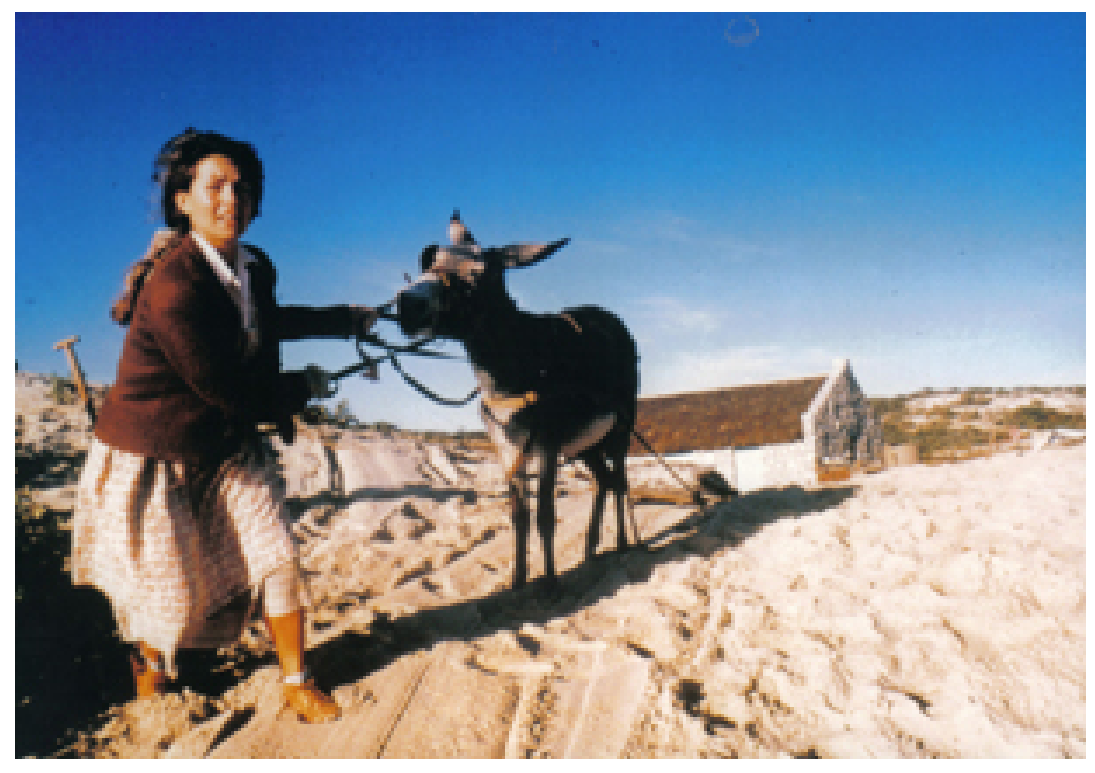

Figure 5: The Story of Klara Viljee

\section{Notes}

1. South African film history is captured in less than 15 books. Developments in early South African cinema (1895-1940) have been chronicled in Thelma Gutsche's The History and Social Significance of Motion Pictures in South Africa: 1895-1940 (1946/72). Other significant studies include Keyan Tomaselli's The Cinema of 
Apartheid: Race and Class in South Africa (1989); Johan Blignaut and Martin Botha's Movies Moguls Mavericks: South African Cinema 1979-1991 (1992); Martin Botha's edited volume, Marginal Lives and Painful Pasts: South African Cinema After Apartheid (2007); Jacqueline Maingard's South African National Cinema (2007); André le Roux and Lilla Fourie's Filmverlede: Geskiedenis van die Suid-Afrikaanse speelfilm (1982); Peter Davis's In Darkest Hollywood: Exploring the Jungles of Cinema's South Africa (1996); Martin Botha and Adri Van Aswegen's Images of South Africa: The Rise of the Alternative film (1992); Tomaselli's compilation of revised and reworked papers and chapters published elsewhere, Encountering Modernity: Twentieth Century South African Cinemas (2006); Isabel Balseiro and Ntongela Masilela's edited volume, To Change Reels: Film and Film Culture in South Africa (2003); Martin Botha's South African Cinema 1896 - 2010 (2012); Lucia Saks's Cinema in a Democratic South Africa: The Race for Representation (2010), as well as Litheko Modisani's South Africa's Renegade Reels: The Making and Public Lives of Black-Centered Films (2013).

2. In Southern Africa, the term Coloureds (also known as Bruinmense, Kleurlinge or Bruin Afrikaners in Afrikaans) is an ethnic label for people of mixed ethnic origin who possess ancestry from Europe, Asia, and various Khoisan and Bantu tribes of Southern Africa.

\section{References}

Balseiro, I. \& Masilela, N. (Eds) To change reels: Film and film culture in South Africa. Detroit, Wayne State University, 2003.

Barnard, C. Paljas \& Die storie van Klara Viljee: Die filmdraaiboeke. Kaapstad, Tafelberg, 1998.

Bickford-Smith, V. \& Mendelsohn, R. 'Film and history studies in South Africa revisited: Representing the African Past on screen'. South African Historical Journal, 48 (2003), pp. 1-9.

Blignaut, J. \& Botha, M.P. (eds) Movies moguls mavericks: South African cinema 1979-1991. Cape Town, Showdata, 1992.

Bisschoff, L. Women in African Cinema: An aesthetic and thematic analysis of filmmaking by women in francophone West Africa and lusophone and anglophone Southern Africa. Unpublished PhD thesis, University of Stirling, 2009.

Botha, M. P. Jans Rautenbach: Dromer, baanbreker en auteur. Kaapstad, Genugtig!, 2006.

2007. (ed.). Marginal lives and painful pasts: South African cinema after apartheid. Cape Town, Genugtig!, South African Cinema 1896 - 2010. Bristol, Intellect, 2012.

Botha, M. P. \& Dethier, H. Kronieken van Zuid-Afrika: De films van Manie van Rensburg. Brussel, VUB Press, 1997.

Botha, M. P. \& Van Aswegen, A. Images of South Africa: The rise of the alternative film. Pretoria, Human Sciences Research Council, 1992.

Burns, Y. M. 'Censorship: Past, present and future'. Ecquid Novi, 11:2 (1990), pp. 148-60.

Caughie, J. (ed.) Theories of authorship: A reader. London, British Film Institute, 1981.

Cameron, J. T. \& Spies, S. B. (eds) An illustrated history of South Africa. Johannesburg, Ball, 1986.

Cook, P. (ed.) The Cinema Book (Third edition): London, British Film Institute, 2007.

Davis, P. In Darkest Hollywood: Exploring the jungles of cinema's South Africa. Randburg, Ravan, 1996.

Giliomee, H. The Afrikaners: Biography of a people. Cape Town, Tafelberg, 2003.

Gutsche, T. The history and social significance of motion pictures in South Africa: 1895-1940. Cape Town, Howard Timmins, 1972. 
Kannemeyer, J. C. Die Afrikaanse literatuur: 1652-1987. Kaapstad, Human \& Rousseau, 1988.

Le Roux, A. Screening wars: War, society, film and public perception - The case of the second Anglo-Boer War: 1899-1902. Unpublished History Honours Dissertation, University of Stellenbosch, 2009.

Le Roux, A. I. \& Fourie, L. Filmverlede: Geskiedenis van die Suid-Afrikaanse speelfilm. Pretoria, Universiteit van Suid-Afrika, 1982.

Maingard, J. South African national cinema. London, Routledge, 2007.

Maule, R. Beyond auteurism: New directions in authorial practices in France, Italy and Spain since the 1980s. Bristol, Intellect, 2008.

Marx, L. Katinka Heyns: Questioning Afrikaans culture. In J. Levitin, J. Plessis \& V. Raoul (eds) Women filmmakers: Refocusing (London, Routledge, 2003), pp. 330-41.

McCluskey, A. T. The devil you dance with: Film culture in the new South Africa. Chicago, University of Illinois Press, 2009.

Modisani, L. South Africa's Renegade Reels: The Making and Public Lives of Black-Centered Films. New York, Palgrave Macmillan, 2013.

Ozynski, J. (ed.) Film: What the censors think. Johannesburg, Anti-Censorship Group, 1989.

Saks, L. Cinema in a democratic South Africa: The race for representation. Bloomington, Indiana University Press, 2010.

Sellors, P. 'Collective Authorship in Film.' The Journal of Aesthetics and Art Criticism 65:3, (Summer 2007), pp. $263-271$.

Film authorship: Auteurs and other myths. Harrow, Middlesex: Wallflower Press, 2010.

Shepperson, A. \& Tomaselli, K.G. 'South African cinema beyond apartheid: Affirmative action in distribution and storytelling'. Social Identities, 6:3 (2000), pp. 323-24.

Thompson, L. A history of South Africa. New Haven, Yale University Press, 2001.

Tomaselli, K. G. The cinema of apartheid: Race and class in South African film. London, Routledge, 1989. Encountering modernity: Twentieth century South African cinemas. Pretoria, Unisa, 2006.

Treffry-Goatley, A. The representation and mediation of a national identity in the production of postapartheid South African cinema. Unpublished PhD thesis, University of Cape Town, 2010.

Udeman, A. The history of the South African film industry 1940-1971: A bibliography. Johannesburg, University of the Witwatersrand, 1972.

Selected Filmography

As actress:

Katrina (1969)

Jannie Totsiens (1970)

Pappa Lap (1971)

Die Sersant en die Tigermoth (1973)

Babbelkous en Bruidegom (1974)

Eendag op 'n Reëndag (1975)

Willem (1976)

Living with Bipolar Disorder (2009) 
As director:

Phoenix en kie (1979)

Die Avonture van Joachim Verwey (1980; co-directed with Manie van Rensburg)

Piet-My-Vrou (1981)

Waar die liefde lê (1983)

Tekwan (1985)

Doffel, Babbel en Bekkie (1986)

Fiela se Kind (1987)

Simon en Sandra (1989)

Kreatiwiteit (1989)

N.P. van Wyk Louw (1989)

Prof Martin Versfeld (1989)

Die Storie van Klara Viljee (1991)

Silwerdoekstories (1994)

Amalia (1995)

Paljas (1997)

The Feast of the Uninvited (2008)

Die Wonderwerker (2012)

\section{Reports}

Photo credits: Fiela se Kind, Paljas and Story of Klara Viljee: Sonneblom Films.

\section{Author Information}

Martin P. BOTHA is Associate Professor of Film and Media Studies at the University of Cape Town. He has published more than 200 articles, reports and papers on South African media, including six books on South African cinema. His most recent book is South African Cinema 1896-2010 (Bristol: Intellect, 2012). 